Original Paper

\title{
Defluorination with Biobriquette during Coal Combustion
}

\author{
Liu DAN \\ (Received November 19, 2010) \\ バイオブリケットによる石炭燃焼時の脱フッ素についての検討 \\ 劉 丹
}

\begin{abstract}
The reduction of fluoride emissions from coal combustions is important to reduce fluoride pollution in the atmosphere. It has been suggested that biobriquettes can be used for both desulfurization and defluorination. In this study, effects on defluorination from two biobriquettes were examined. One of the biobriquettes was made by mixing powdered coal, powdered bamboo and $\mathrm{Ca}(\mathrm{OH})_{2}$. The other biobriquette was made by mixing powdered coal, and powdered bamboo covered by $\mathrm{Ca}(\mathrm{OH})_{2}$. The molar equivalency of $\mathrm{Ca}$ to $\left(\mathrm{F}_{2}+\mathrm{S}\right)$ was 2 in both of the biobriquettes. The combustion temperature of the furnace was $600{ }^{\circ} \mathrm{C} \sim 900{ }^{\circ} \mathrm{C}$. The results showed that both of the biobriquettes have high efficiencies on defluorination of coal, and the efficiency of the one made with bamboo covered by $\mathrm{Ca}(\mathrm{OH})_{2}$ is higher. The defluorination efficiency increases with decreasing temperature. The concentration of $\mathrm{SO}_{2}$ emitted from the biobriquettes made with bamboo covered by $\mathrm{Ca}(\mathrm{OH})_{2}$ is lower at the same combustion condition. This study shows that biobriquettes are promising for defluorination of coals.
\end{abstract}

\section{Key Words}

Coal, Combustion, Bamboo, biobriquette, Defluorination

\section{1. 緒 言}

中国では急速な経済成長に伴って石炭の消費量は増加して いく一方である。2010 年において石炭の消費量は 114.5 億卜 ン，世界の全体の消費量の $13.9 \%$ を占める ${ }^{1)}$ 。石炭の大量消費 による SOx や煤塵などの大気污染問題がなお一層深刻化する ことが予想される。中国の大気污染物質の健康へもたらす影 響としてはSOxによる呼吸器系疾患が主として問題とされて いたが，近年，これに加えてフッ素による歯や骨への被害(斑

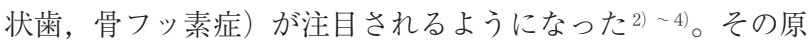
因は中国炭に含まれるフッ素含有量の平均值が世界平均值よ り 3 倍以上も高い $248 \mathrm{ppm}$ であり ${ }^{3)}$ ，石炭燃焼時の大気フッ 素污染，特に民生用石炭の使用による室内フッ素污染が引き 起こされているためと考えられる。

中国の石炭燃焼によるフッ素污染地域では，一人当たりの 成人一日のフッ素摂取量は $9.70 \mathrm{mg}$ であった3)。フッ素一日摂 取量の限界值 $8 \mathrm{mg}^{5}{ }^{5}$ を超えているため, フッ素過剩摂取によ り人々はフッ素症が多くみられる。また, 中国の石炭然焼に

Department of Chemical Science of Engineering,

Ariake National College of Technology

150, Higashio-machi, Omuta-shi, Fukuoka 836-8585, Japan
よるフッ素污染は主に雲南, 貴州, 四川, 湖南, 湖北, 山西, 河北, 河南等 14 の省に所属している約 200 の県で発生し, こ れらのフッ素污染地域にはおよそ 3400 万人が居住している。 フッ素污染地域にはフッ素症患者が多く，すでに中国では フッ素症は地方病として認定されている3》。そのうち, フッ素 污染の最も深刻な貴州省では, フッ素症の患者人数は 1000 万 を超えた ${ }^{4)}$ 。

中国市民の健康を維持するためには，フッ素含有量の高い 石炭の使用を減らすべきであるが, 中国のエネルギー事情と 田舎の農民の経済状況から考えるとこれは極めて難しい。 フッ素公害から農民を守るためには，石炭燃焼からのフッ素 の排出を抑制することが急務である。

これまでの研究で筆者は, 中国炭中のフッ素の存在形態, 燃 焼の際に生じた排ガス中のフッ素の形態，燃焼灰中の形態お よび燃焼の際に生じたフッ素の挙動を明らかにした ${ }^{6) （ 9) 。 ま ~}$ た，石炭燃焼の際に生じたフッ素化合物の排出を抑制する方 法としては, (1)燃焼前に石炭中から無機フッ素化合物を除去

\footnotetext{
有明工業高等専門学校 物質工学科

于 836-8585 福岡県大牟田市東萩尾町 150
} 
する事前脱フッ素法，(2)石炭燃焼後の排ガスからHFを除去す る排煙脱フッ素法，(3)石炭燃焼と同時にHFを除去する炉内脱 フッ素法がある。(1)の石炭事前脱フッ素法により, 石炭を使 用する前に洗炭を行えばフッ素が含まれる無機物の除去が可 能である。しかし，中国では洗炭率が低く，2007年の洗炭率 は石炭生産量の $24.77 \%$ にし至っておらず，先進国の60\% 95\%と比べてはるかに低い ${ }^{10)}$ 。また, 水不足の中国で洗炭を 行うのは容易でなく, 洗炭後の排水処理の費用が高い。また, (2)の排煙からのHFを取り除くことは排煙の設備や排煙ガスを 吸収するアルカリ溶液が必要になるので, 民生用炉（ストー ブ）を使用している家庭での実施には困難である。したがっ て, 石炭燃焼と同時にHFを除去する炉内脱フッ素法が最も適 していると考え, 本研究では(3)の石炭燃焼と同時にHFを除去 する炉内脱フッ素法を対象とした。

石炭は中小ボイラー, ストーブ然料として使われており, 中 小ボイラーとストーブへのバイオブリケットが使用可能であ ることはすでに検証されている11) 13)。

上述したように，民生用ストーブの石炭燃焼の際には炉内 脱フッ素法が適していると考えられる。有効な脱フッ素剂を 選び, バイオマス, 石炭粉末とバイオブリケットを作製し, こ れを石炭燃焼排ガス中のHFと反応させてフッ素化合物として 石炭燃焼灰中に固定させることによって, 燃焼排ガス中の フッ素の排出量を減らすことができる。中国の民生用石炭使 用量は2006年には8386.34万トンに上ったので14)，炉内脱フッ 素が可能になれば, 民生用石炭燃焼からのフッ素污染予防に 繋がると考えられる。

一方, 中国のバイオマス資源は非常に豊富であり, 作物の わらや茎の量は年間 3 億 $~ 3.5$ 億卜ンにも上る ${ }^{15)}$ 。また，中国 のフッ素污染地域には竹が非常に多く, バイオマスとして利 用ができる。すなわち，中国ではバイオブリケットを作製す る際のバイオマス原料は充実していると考えられる。なお，バ イオマスの燃焼は熱を放出するため, 熱エネルギー源として も利用できる。また，バイオマスの燃焼は $\mathrm{CO}_{2}$ の排出量が“ゼ ロ”とされるため, 化石燃料の燃焼による地球温暖化の防止 に役に立つものである。

本研究は竹をバイオマスとして石炭粉末と混合し, バイオ ブリケットを作製した。また，バイオブリケット燃焼の際の 炉内脱フッ素効果を狙い, $\mathrm{Ca}(\mathrm{OH})_{2}$ を脱フッ素剂として利用 した。本研究はバイオブリケットを民生用石炭として燃焼す る際の燃焼ガス中のフッ素排出抑制, フッ素症の予防を目的 とする。

\section{2. 実 験}

実験に用いた燃焼装置を Fig. 1 に示す。吸収瓶への配管部 分は $300 \mathrm{~mm}$ とし，吸収瓶と燃焼炉の距離を接近させた。こ れは, 石炭燃焼時の排ガス中のフッ素化合物が配管部に吸着 或いは付着し，測定誤差となるのを防ぐためである。燃焼炉 とした石英管の長さは $760 \mathrm{~mm}$ ，内径は $25 \mathrm{~mm}$ ，外径 $28 \mathrm{~mm}$, 電気炉加熱部の長さ $300 \mathrm{~mm}$, 直径 $30 \mathrm{~mm}$ であった。温度制 御は，石英管外側に配置した熱電対を用いて行った。但し，炉 内温度はあらかじめ測定し，補正した值を用いた。

本研究は中国産の蓮塘炭を用いて実験を行った。Table 1と Table 2-1に蓮塘炭の工業分析結果と元素分析結果を示す。 Table 1とTable 2-1に示したように, 蓮塘炭の灰分が多く, 発 熱量はかなり低いのが特徵である。また, Table 3に蓮塘炭の 蛍光 X 線分析による半定量 (SQX) 分析結果（酸化物の wt\% に換算）を示す。

\section{1 バイオマスとした竹のフッ素含有量の測定}

本研究は竹をバイオマスとしてバイオブリケットを作製し た。使用した竹は地域の里山整備した際に生じたものであり, 種類は特定していない。一般的に, 生竹のC, H, Oの含有量 が木材とほぼ同程度 ${ }^{16)}$ であり, その元素分析結果を Table 2-2 に示す。また, カルシウムの存在を確認したが微量のため存 在形態の確認が困難である。そこで，本研究はFig. 1の装置を 用いて竹粉末を燃焼し, 竹からフッ素の放出及び放出量につ いて確認し，竹自身の燃焼時の脱フッ素効果について検討し た。

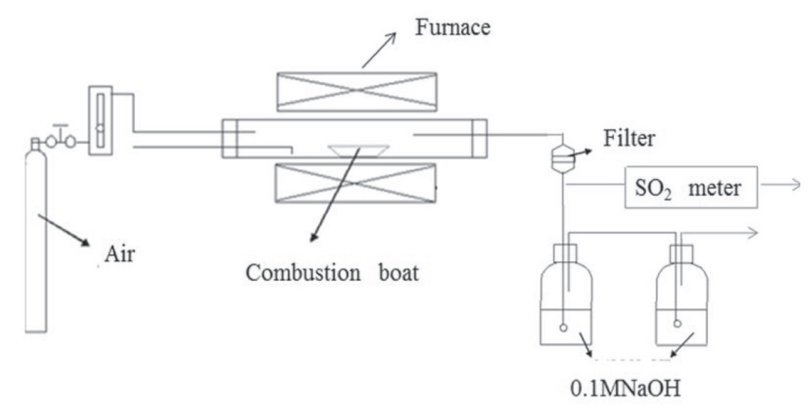

Fig. 1 Schematic of experimental set-up

Table 1 Proximate analysis of Liantang coal (wt\%, air-dry)

\begin{tabular}{c|c|c|c|c|c}
\hline Sample & Moisture & Ash & VM & FC & Fuel ratio \\
\hline Liantang & 0.5 & 86.7 & 3.8 & 9.0 & 2.37 \\
\hline
\end{tabular}

Table 2-1 Ultimate analysis of Liantang coal (wt\%, daf- basis)

\begin{tabular}{c|c|c|c|c|c|c}
\hline Samples & $\mathrm{C}$ & $\mathrm{H}$ & $\mathrm{N}$ & $\mathrm{S}$ & $\mathrm{O}$ & $\mathrm{F}(\mu \mathrm{g} / \mathrm{g})$ \\
\hline Liantang & 65.7 & 2.3 & 1.6 & 12.7 & 17.7 & 2407 \\
\hline
\end{tabular}

Table 2-2 Ultimate analysis of bamboo (wt\%, daf- basis)

\begin{tabular}{c|c|c|c|c|c|c|c|c}
\hline Sample & $\mathrm{C}$ & $\mathrm{H}$ & $\mathrm{N}$ & $\mathrm{S}$ & $\mathrm{O}$ & $\mathrm{Cl}$ & $\mathrm{F}(\mu \mathrm{g} / \mathrm{g})$ & other \\
\hline Bamboo & 50.0 & 6.4 & 0.3 & 0.02 & 43.0 & 0.2 & 260 & 0.08 \\
\hline
\end{tabular}


Table 3 SQX analysis of Liantang coal

\begin{tabular}{c|c}
\hline Composition & wt\% \\
\hline $\mathrm{C}$ & 2.43 \\
\hline $\mathrm{F}$ & 0.24 \\
\hline $\mathrm{Na}_{2} \mathrm{O}$ & 0.0545 \\
\hline $\mathrm{MgO}$ & 0.499 \\
\hline $\mathrm{Al}_{2} \mathrm{O}_{3}$ & 5.25 \\
\hline $\mathrm{SiO}_{2}$ & 75.5 \\
\hline $\mathrm{P}_{2} \mathrm{O}_{5}$ & 2.11 \\
\hline $\mathrm{SO}_{3}$ & 3.49 \\
\hline $\mathrm{K}_{2} \mathrm{O}$ & 2.14 \\
\hline $\mathrm{CaO}_{2}$ & 4.88 \\
\hline $\mathrm{TiO}_{2}$ & 0.299 \\
\hline $\mathrm{V}_{2} \mathrm{O}_{5}$ & 0.409 \\
\hline $\mathrm{Cr}_{2} \mathrm{O}_{3}$ & 0.0651 \\
\hline $\mathrm{Fe} \mathrm{O}_{3}$ & 2.31 \\
\hline $\mathrm{NiO}_{2 \mathrm{O} O}$ & 0.0356 \\
\hline $\mathrm{CuO}_{2 n}$ & 0.0204 \\
\hline $\mathrm{As}_{2} \mathrm{O}_{3}$ & 0.0791 \\
\hline $\mathrm{Rb}_{2} \mathrm{O}$ & 0.0158 \\
\hline $\mathrm{SrO}_{2}$ & 0.0059 \\
\hline $\mathrm{Y}_{2} \mathrm{O}_{3}$ & 0.0199 \\
\hline $\mathrm{ZrO}_{2}$ & 0.0069 \\
\hline $\mathrm{MoO}_{3}$ & 0.007 \\
\hline $\mathrm{BaO}_{2}$ & 0.0104 \\
\hline & 0.157 \\
\hline
\end{tabular}

\section{$2.2 \mathrm{Ca}(\mathrm{OH})_{2}$ 担持竹粉末の作製}

$\mathrm{Ca}(\mathrm{OH})_{2}$ 担持竹粉末の作製には粒径 $0.2 \mathrm{~mm}$ の乾燥した竹粉 末および市販のCa $(\mathrm{OH})_{2}$ を用いた。なお,バイオブリケットを作 製する際, 石炭の割合は 80wt\%, 竹バイオマスは 20wt\% ${ }^{17)}{ }^{18)}$, 脱フッ素剤・脱硫剤である $\mathrm{Ca}(\mathrm{OH})_{2}$ の使用量が竹バイオブリ ケット中の蓮塘炭に含まれた硫黄とフッ素とのモル比 $\mathrm{Ca} / \mathrm{S}$ $\left.+\mathrm{F}_{2}\right)=2^{7)}$ にした。例えば，重さ $1 \mathrm{~g}$ の竹バイオブリケット $\left(\mathrm{Ca}(\mathrm{OH})_{2}\right.$ の重量を除いて $)$ 中に含まれる竹バイオマスの重量 は $0.2 \mathrm{~g}(20 \mathrm{wt} \%)$, 蓮塘炭重量は $0.8 \mathrm{~g}(80 \mathrm{wt} \%)$ である。 $0.2 \mathrm{~g}$ 竹バイオマス中の $\left(\mathrm{S}+\mathrm{F}_{2}\right)$ 物質量は $1 \times 10^{-6} \mathrm{~mol}$ であり，ま た，蓮塘炭 $0.8 \mathrm{~g}$ 中に含まれる $\left(\mathrm{S}+\mathrm{F}_{2}\right)$ の物質量は $5 \times 10^{-4} \mathrm{~mol}$ である。すなわち, $1 \mathrm{~g}$ の竹バイオブリケット中の $\left(\mathrm{S}+\mathrm{F}_{2}\right)$ モル数 $=\left(1 \times 10^{-6} \mathrm{~mol}+5 \times 10^{-4} \mathrm{~mol}\right) \doteqdot 5 \times 10^{-4} \mathrm{~mol}$ であ る。モル比 $\mathrm{Ca} /\left(\mathrm{S}+\mathrm{F}_{2}\right)=2$ にするため, $\mathrm{Ca}$ の物質量を $10 \times$ $10^{-4} \mathrm{~mol}$ によければならない。 $10 \times 10^{-4} \mathrm{~mol} \mathrm{Ca} \mathrm{Ca}(\mathrm{OH})_{2}$ の 重量に換算すると $0.074 \mathrm{~g}$ になる。すなわち,竹バイオマス $0.2 \mathrm{~g}$ $(20 \mathrm{wt} \%)$ に $0.074 \mathrm{~g} \mathrm{Ca}(\mathrm{OH})_{2}$ を担持させ， $0.8 \mathrm{~g}$ (80wt\%) の 蓮塘炭粉末と混合して竹バイオブリケットを作製すると，竹 バイオブリケット中のモル比 $\mathrm{Ca} /\left(\mathrm{S}+\mathrm{F}_{2}\right)=2$ となる。

上述したように, 重量割合は竹バイオマス: $\mathrm{Ca}(\mathrm{OH})_{2}=0.2 \mathrm{~g}$ : $0.074 \mathrm{~g}=2.7: 1$ とし, $\mathrm{Ca}(\mathrm{OH})_{2}$ を測り,竹粉末の細孔体積 ${ }^{19)}$ を 参考にして純水を加えて $\mathrm{Ca}(\mathrm{OH})_{2}$ 溶液を作成し，また $\mathrm{Ca}(\mathrm{OH})_{2}$ の 2.7 倍重量の竹粉末が $\mathrm{Ca}(\mathrm{OH})_{2}$ 溶液を完全に吸収した後, $105{ }^{\circ} \mathrm{C}$ の乾燥機で 24 時間乾燥し, $\mathrm{Ca}(\mathrm{OH})_{2}$ 担持竹粉末の作製 ができる。
本来, Table 3に示したように, 蓮塘炭中にもカルシウムが 存在している。しかし, 蓮塘炭中のカルシウムは $\mathrm{Ca}(\mathrm{OH})_{2}$ と しての存在が認められず，確認できたのは $\mathrm{Ca}_{3}\left(\mathrm{PO}_{4}\right)_{3}(\mathrm{~F}, \mathrm{Cl}$, $\mathrm{OH})$ (燐灰石) と $\mathrm{CaCO}_{3}$ である ${ }^{7)}{ }^{8)}$ 。燐灰石中のカルシウムは 石炭燃焼時に生じたフッ素と $\mathrm{SO}_{2}$ が反応しないため, 脱フッ 素と脱硫に役に立たない。また $\mathrm{CaCO}_{3}$ は $750^{\circ} \mathrm{C}$ 以上の熱分解 温度7にならない, 脱フッ素と脱硫効果がない。 $750^{\circ} \mathrm{C}$ 以上 になると，石炭中の $\mathrm{CaCO}_{3}$ が熱分解して $\mathrm{CaO}$ が生じる $\left(\mathrm{CaCO}_{3}\right.$ $\left.=\mathrm{CaO}+\mathrm{CO}_{2}\right)$ 。生じた $\mathrm{CaO}$ は竹バイオブリケット燃焼時に 生成したフッ素と $\mathrm{SO}_{2}$ と反応を起し, 脱フッ素と脱硫効果を もたらすと考えられる。しかし, 蓮塘炭中の $\mathrm{CaCO}_{3}$ の存在は 確認できたが微量のため定量ができなかった。さらに，本実 験では, 竹バイオブリケットを $>750^{\circ} \mathrm{C}$ 燃焼する際，フッ素と $\mathrm{SO}_{2}$ の排出が $<750^{\circ} \mathrm{C}$ の燃焼時より多いため, 蓮塘炭自身に含ま れた $\mathrm{CaCO}_{3}$ にる脱フッ素と脱硫を期待できないと判断する。 そのため, 本研究は脱フッ素剤として $\mathrm{Ca}(\mathrm{OH})_{2}$ を利用した。

\section{3 ブリケットの作製}

粒径 $0.2 \mathrm{~mm}$ である蓮塘炭粉末と竹粉末を用いて, 2.5 ton/ $\mathrm{cm}^{2}$ の成形圧力で高さ・直径 $1.0 \mathrm{~cm}$ の円柱状のブリケット四 種を作製した。

1）蓮塘炭粉末（100wt％）を用いて作製した石炭ブリケット。

2) 蓮塘炭粉末 (80wt\%) と竹粉末 (20wt\%) を混合し，作製 した竹バイオブリケット。

3) 蓮塘炭粉末 (80wt\%), 竹粉末 $(20 \mathrm{wt} \%)$ と $\mathrm{Ca}(\mathrm{OH})_{2}$ (モル 比 $\left.\mathrm{Ca} /\left(\mathrm{S}+\mathrm{F}_{2}\right)=2\right)$ を混合し, 作製した $\mathrm{Ca}(\mathrm{OH})_{2}$ 混合竹バ イオブリケット(竹バイオブリケット中には石炭粉末 $0.8 \mathrm{~g}$, 竹バイオマス $0.2 \mathrm{~g}, \mathrm{Ca}(\mathrm{OH})_{2}$ は $0.074 \mathrm{~g}$ になる。 $\mathrm{Ca}(\mathrm{OH})_{2}$ の重量を除くと, $1 \mathrm{~g}$ 竹バイオブリケット中には蓮塘炭粉 末 $0.8 \mathrm{~g}$ ，竹バイオマス $0.2 \mathrm{~g}$ である)。

4) 蓮塘炭粉末 $(80 \mathrm{wt} \%) ， 2.2$ で作製した $\mathrm{Ca}(\mathrm{OH})_{2}$ を担持した 竹粉末 $0.274 \mathrm{~g}$ と混合して作製した $\mathrm{Ca}(\mathrm{OH})_{2}$ 担持竹バイオ ブリケット $\left(\mathrm{Ca}(\mathrm{OH})_{2}\right.$ の重量を除くと， $1 \mathrm{~g}$ 竹バイオブリ ケット中には蓮塘炭粉末 $0.8 \mathrm{~g}, 0.2 \mathrm{~g}$ 竹バイオマス中に $0.074 \mathrm{~g}$ の $\mathrm{Ca}(\mathrm{OH})_{2}$ を担持している $)$ 。

\section{4 各種ブリケット燃焼の際に排出されたフッ素の濃度及 び脱フッ素率の測定}

燃焼温度は $600^{\circ} \mathrm{C}, 700^{\circ} \mathrm{C}, 800^{\circ} \mathrm{C}, 900^{\circ} \mathrm{C}$ に設定した7)17)。作 製したブリケットを置いてある燃焼皿を石英棒で燃焼炉の中 心部に押し入れ，空気流量を $0.51 / \mathrm{min} に$ 設定し，燃焼を行っ た。燃焼した際に発生したガスを吸収瓶（吸収液 $200 \mathrm{ml}, 0.1$ $\mathrm{mol} / 1 \mathrm{NaOH}$ 溶液) で捕集した。また，吸収液を $50 \mathrm{ml}$ 取り, 更に緩衝液 TISAB（JISK0105 参考） $50 \mathrm{ml}$ を加え, 複合フッ 素イオン電極（HORIBA 製）を用いて，溶液中のフッ素の濃 度を測定し, 各種ブリケット燃焼時の放出フッ素の濃度を求 めた。さらに, $\mathrm{Ca}(\mathrm{OH})_{2}$ を含むブリケットの脱フッ素率は式 (1)で計算した。 
脱フッ素率 $\eta \%$

$$
=\frac{\left[F^{-}\right](C a /(S+F 2)=0)-\left[F^{-}\right](C a /(S+F 2)=2)}{\left[F^{-}\right](C a /(S+F 2)=0)} \times 100
$$

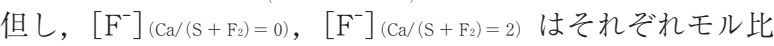
$\mathrm{Ca} /\left(\mathrm{S}+\mathrm{F}_{2}\right)=0$ (バイオブリケット中 $\mathrm{Ca}(\mathrm{OH})_{2}$ が含まれてい ない), $\mathrm{Ca} /\left(\mathrm{S}+\mathrm{F}_{2}\right)=2$ の際，ブリケット燃焼により排出さ れたガスを吸収した $\mathrm{NaOH}$ 溶液中の石炭単位重量 (1 g) 当り のフッ素イオンの濃度である。

\subsection{SEM 実験}

竹粉末の内部構造, $\mathrm{Ca}(\mathrm{OH})_{2}$ を担持した竹粉末の $\mathrm{Ca}(\mathrm{OH})_{2}$ 担持状態を確認するために SEM を用いて観察を行った。

\section{6 竹バイオブリケット燃焼温度と脱フッ素率の関係}

二種の $\mathrm{Ca}(\mathrm{OH})_{2}$ を含む（混合，担持）竹バイオブリケット をそれぞれ $600^{\circ} \mathrm{C}, 700^{\circ} \mathrm{C}, 800^{\circ} \mathrm{C}, 900^{\circ} \mathrm{C}$ で燃焼した。燃焼す る際の排ガスを $0.1 \mathrm{~mol} / 1$ の $\mathrm{NaOH}$ 溶液によって吸収し, 放出 フッ素濃度を測定した。また，式(1)を用いて脱フッ素率を算 出し，二種の $\mathrm{Ca}(\mathrm{OH})_{2}$ を含む (混合，担持) 竹バイオブリケッ トの脱フッ素率と燃焼温度の関係について検討した。

\section{7 竹バイオブリケットの脱硫率について}

石炭ブリケット， $\mathrm{Ca}(\mathrm{OH})_{2}$ を担持した竹粉末で作製した竹 バイオブリケットと $\mathrm{Ca}(\mathrm{OH})_{2}$ を混合した竹バイオブリケット を燃焼時の $\mathrm{SO}_{2}$ 放出状態について追跡した。また，それぞれ の $\mathrm{SO}_{2}$ 放出量に基づいて, 式(2)を用いて脱硫率 $\eta$ ’を算出し た。

脱硫率 $\eta$, \%

$$
=\frac{\left[\mathrm{SO}_{2}\right]_{(\mathrm{Ca} /(\mathrm{S}+F 2)=0)}-\left[\mathrm{SO}_{2}\right]_{(\mathrm{Ca} /(\mathrm{S}+F 2)=2)}}{\left[\mathrm{SO}_{2}\right]_{(\mathrm{Ca} /(\mathrm{S}+F 2)=0)}} \times 100
$$

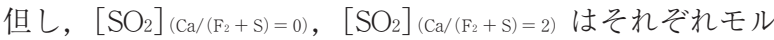
比 $\mathrm{Ca} /\left(\mathrm{F}_{2}+\mathrm{S}\right)=0$ (バイオブリケット中 $\mathrm{Ca}(\mathrm{OH})_{2}$ が含まれて いない)， $\mathrm{Ca} /\left(\mathrm{F}_{2}+\mathrm{S}\right)=2$ の際，ブリケット燃焼により排出 されたガスに含まれた $\mathrm{SO}_{2}$ 濃度である。

\section{3. 結果及び考察}

\section{1 竹のフッ素含有量}

竹粉末中のフッ素含有量を測定した結果， $260 \mu \mathrm{g} / \mathrm{g}(260$ ppm)のフッ素が含まれることを確認した。竹を燃焼する際に フッ素を放出したことは，竹の中に存在していたカルシウム は脱フッ素に役に立たないか或いは脱フッ素の効果が高くな いと言える。また，この実験に使用した蓮塘炭のフッ素含有量 は2 $2407 \mathrm{ppm}$ であるため,竹のフッ素含有量は蓮塘炭の約 $1 / 10$ であることが判明した。竹バイオブリケット中の竹の割合は 20wt％であるため, 燃焼する際, 排出ガス中のフッ素排出量 は石炭ブリケットより少ないことになる。また，乾燥した竹 の発熱量は約 $7000 \mathrm{~J} / \mathrm{g}^{20)}$ であり，今回実験に用いた石炭の重 量当たり約 2 倍の発熱量であることがわかった。すなわち，本 実験で使用した竹と蓮塘炭で作製した竹バイオブリケットは
同重量の蓮塘炭ブリケットより高い熱エネルギーを得られる ことになる。

\section{2 ブリケット燃焼時の放出フッ素濃度の測定}

蓮塘炭ブリケットおよび竹バイオブリケット $\left(\mathrm{Ca}(\mathrm{OH})_{2}\right.$ が 含まれていない）燃焼時の温度变化における放出フッ素量を Fig. 2 に示す。

二種のブリケットは，炉の燃焼温度の増加に伴って排ガス 中のフッ素放出量が増加した。これは，燃焼温度上昇と共に 石炭中に含まれる無機フッ素化合物の熱分解率が高くなり, また，燃焼率が高くなるにつれて，石炭中の有機フッ素化合 物によるフッ素の排出が増加したためと考えられる。蓮塘炭 中のフッ素の形態は，無機フッ素化合物である白雲母 $\left(\mathrm{KAl}_{3} \mathrm{Si}_{3} \mathrm{O}_{10}(\mathrm{OH}, \mathrm{F})_{2}\right)$, 燐灰石 $\left(\mathrm{Ca}_{5}\left(\mathrm{PO}_{4}\right)_{3} \mathrm{~F}\right)$ ，拈よび- $\mathrm{CF}_{2}$ - (有 機構造) となっている。また，燐灰石は590 ${ }^{\circ} \mathrm{Cで}$ 熱分解し，さ らに $850{ }^{\circ} \mathrm{C}$ 前後で白雲母の熱分解が起こるため, フッ素を多 く放出することが明らかになっている677)。今回実験に用いた 蓮塘炭中には燐灰石 $3 \%$, 白雲母 $15 \%^{7)}$ が含まれ，白雲母の 量がはるかに多いため，石炭燃焼時のフッ素の放出は白雲母 によるものだと考えられる。そのため，蓮塘炭ブリケット燃 焼の際の放出フッ素量は $800{ }^{\circ} \mathrm{C} \sim 900{ }^{\circ} \mathrm{C}$ で急激に上昇した。 また竹バイオブリケットにおいては，バイオマスは着火性が 良く，燃焼率が高いため，炉の設定温度が同じである場合は， 蓮塘炭ブリケットより高い温度を持つことになると考えられ る。そのため，竹バイオブリケット中の白雲母の熱分解が速 まり，700 ${ }^{\circ} \mathrm{C} \sim 800{ }^{\circ} \mathrm{C}$ での燃焼排ガス中の放出フッ素量が急 激に上昇したと考えられる。

なお，竹粉末を混入することによって竹バイオブリケット 中の石炭燃焼からの排出フッ素量は減少しなかったため, 竹 自身に石炭燃焼の放出フッ素に対して脱フッ素効果はないと 考えられる。

\section{$3.3 \mathrm{Ca}(\mathrm{OH})_{2}$ による脱フッ素効果}

$\mathrm{Ca}(\mathrm{OH})_{2}$ による石炭燃焼時の脱フッ素効果が明らかになっ ている。また， $\mathrm{Ca}(\mathrm{OH})_{2}$ が石炭粉末への混合割合，すなわち モル比 $\mathrm{Ca} /\left(\mathrm{S}+\mathrm{F}_{2}\right)$ が増加することにより, 石炭燃焼時に放出

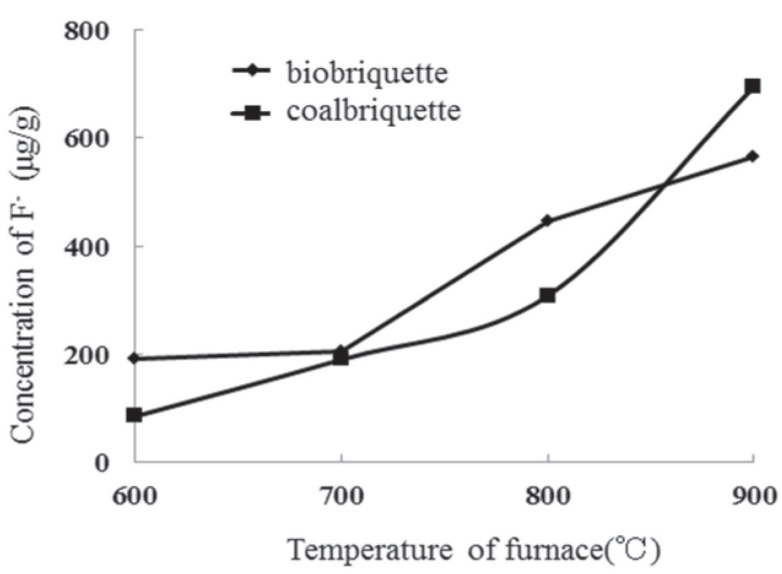

Fig. 2 Discharge fluorides from two sorts of briquettes $\left({ }^{\circ} \mathrm{C}\right)$ 
するフッ素との反応率が高くなり, 脱フッ素率が高くなる ${ }^{719) 。 ~}$ しかし，石炭の着火性と燃焼性を考えると，モル比 $\mathrm{Ca} /(\mathrm{S}+$ $\left.\mathrm{F}_{2}\right)=2$ は最も適切であった ${ }^{17)}$ 。

Fig. 3 にはモル比 Ca/ $\left(\mathrm{S}+\mathrm{F}_{2}\right)=2$ で作製した $\mathrm{Ca}(\mathrm{OH})_{2}$ を混 合した竹バイオブリケット, $\mathrm{Ca}(\mathrm{OH})_{2}$ を担持したバイオブリ

ケット燃焼時の温度変化における放出フッ素量を示す。

竹バイオブリケット中に $\mathrm{Ca}(\mathrm{OH})_{2}$ が含まれると, 温度 $460{ }^{\circ} \mathrm{C}$ に達する際に式 (3)により $\mathrm{Ca}(\mathrm{OH})_{2}$ の熱分解が起こる。Ca $(\mathrm{OH})_{2}$ の熱分解により生成された $\mathrm{CaO}$ は，バイオブリケット燃焼時 に生じたフッ素と式(4)のように脱フッ素反応を起こす。その ため, 排ガス中のフッ素濃度が減り, 脱フッ素効果をもたらす。

$$
\mathrm{Ca}(\mathrm{OH})_{2}=\mathrm{CaO}+\mathrm{H}_{2} \mathrm{O}
$$

$\mathrm{CaO}+2 \mathrm{HF}=\mathrm{CaF}_{2}+\mathrm{H}_{2} \mathrm{O}$

また, $\mathrm{Ca}(\mathrm{OH})_{2}$ 担持竹バイオブリケットの放出フッ素量は, $\mathrm{Ca}(\mathrm{OH})_{2}$ を混合した竹バイオブリケットの放出フッ素量より 少ないことがわかった。これは，竹の特有な多孔構造による ものだと考えられる。竹粉末の比表面積が大きく, $\mathrm{Ca}(\mathrm{OH})_{2}$ が 竹粉末の表面上に広く分布することで，担持竹バイオブリ ケット燃焼時に放出するフッ素との接触確率が高くなり，反 応率が高く高い脱フッ素率に繋がったと考えられる。一方, $\mathrm{Ca}(\mathrm{OH})_{2}$ 混合した竹バイオブリケットは $\mathrm{Ca}(\mathrm{OH})_{2}$ 担持竹バイ オブリケットのように $\mathrm{Ca}(\mathrm{OH})_{2}$ がバイオブリケット中に広く 分散できず，フッ素との反応率が低く，脱フッ素率が低かっ

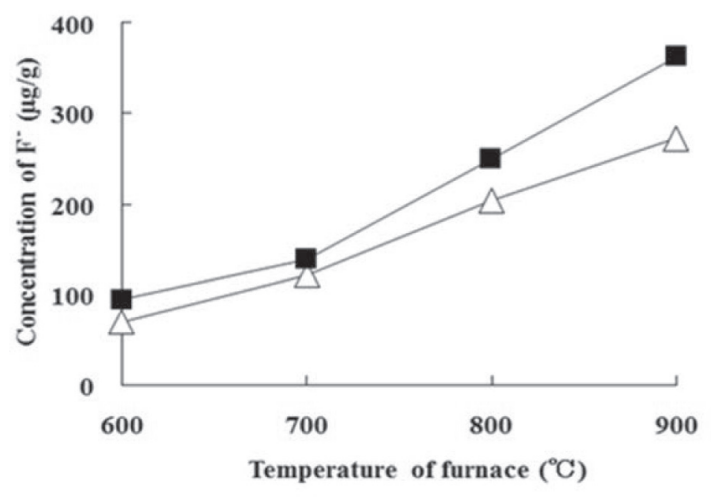

- powdered coal mixed with powdered bamboo and $\mathrm{Ca}(\mathrm{OH})_{2}$ $\triangle$ powdered coal mixed with powdered bamboo covered by $\mathrm{Ca}(\mathrm{OH})_{2}$

Fig. 3 Discharge fluorides from two sorts of biobriquettes

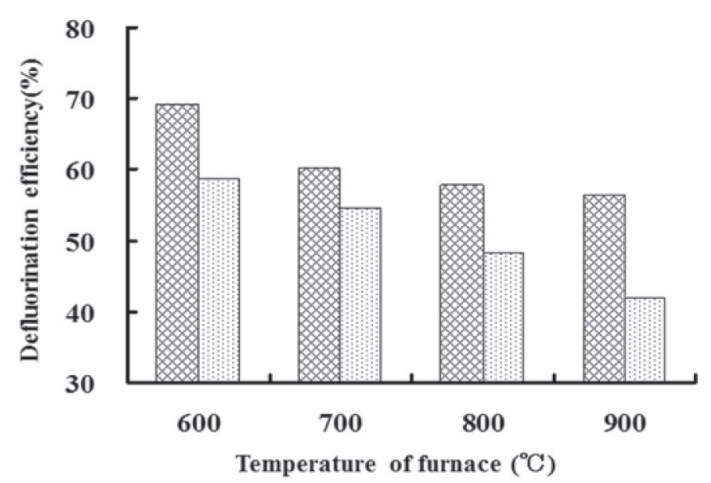

powdered coal mixed with powdered bamboo and $\mathrm{Ca}(\mathrm{OH})$

powdered coal mixed with powdered bamboo covered by $\mathrm{Ca}(\mathrm{OH})_{2}$

Fig. 4 Relationship between temperature and defluorination efficiency
たため, $\mathrm{Ca}(\mathrm{OH})_{2}$ 担持竹バイオブリケットよりフッ素を多く 放出したと考えられる。

なお，Fig. 4 に二種の $\mathrm{Ca}(\mathrm{OH})_{2}$ を含む(混合，担持) 竹バイ オブリケットの各燃焼温度における脱フッ素率を示す。Fig. 4 に示したように，各燃焼温度における $\mathrm{Ca}(\mathrm{OH})_{2}$ を担持した竹 バイオブリケットの脱フッ素率が $\mathrm{Ca}(\mathrm{OH})_{2}$ を混合した竹バイ オブリケットより高い。これは，上述したように担持竹バイ オブリケット中 $\mathrm{Ca}(\mathrm{OH})_{2}$ が竹粉末の表面上に広く分布し, フッ素との接触確率が高く反応率が高く,脱フッ素率が高かっ たからだ考えられる。また, Fig. 4には燃焼温度が上昇する につれて二種のバイオブリケットの脱フッ素率が低くなるこ とを示した。これは，バイオブリケットの燃焼温度が高くな ると, 蓮塘炭中に含まれた無機フッ素化合物の熱分解率が高 くなることによりフッ素の放出量が多くなり，また，有機フッ 素化合物の燃焼率が高くなることによりフッ素の放出量が多 くなるため, カルシウムとフッ素のモル比が下がる。よって, フッ素との反応率が低く, 結果として脱フッ素率が低くなっ たと考えられる。

なお，式(4)の脱フッ素反応で生じた $\mathrm{CaF}_{2}$ が燃焼温度 1400 ${ }^{\circ} \mathrm{C}$ に達成しない限り熱分解はしない7)。したがって, 本研究の 民生用炉での燃焼温度では捕捉フッ素の再放出がないと考え られる。

\section{4 竹粉末と $\mathrm{Ca}(\mathrm{OH})_{2}$ を担持した竹粉末の SEM 観察}

3.3 の結果により，竹バイオブリケットを作製する際，

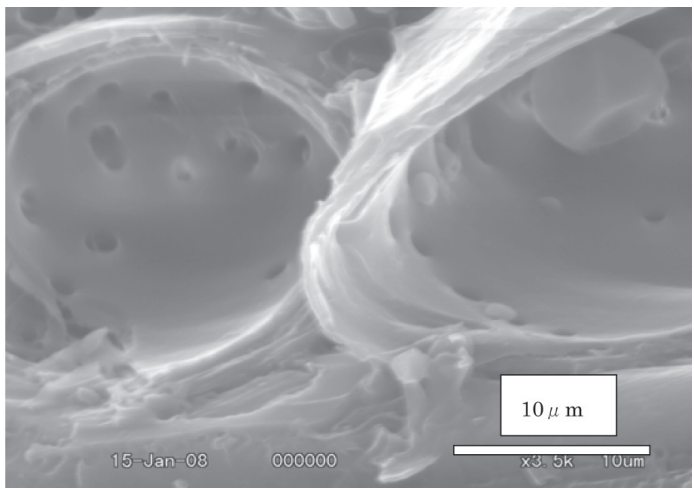

Fig. 5 SEM image of bamboo before treatment

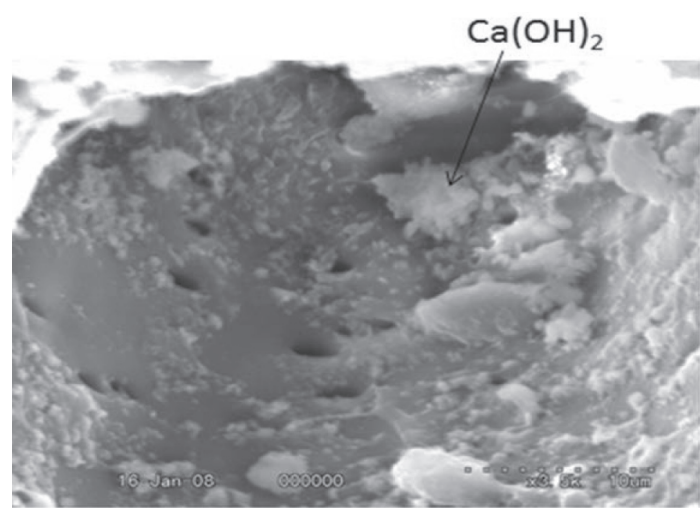

Fig. 6 SEM image of bamboo after treatment 
$\mathrm{Ca}(\mathrm{OH})_{2}$ 担持竹粉末を使用すると，竹バイオブリケット燃焼 時の放出ガス中に含まれたフッ素の濃度は $\mathrm{Ca}(\mathrm{OH})_{2}$ を混合し た竹バイオブリケットよりも減少することが明らかになった。 $\mathrm{Ca}(\mathrm{OH})_{2}$ 担持竹バイオブリケットの放出フッ素量が減少した 原因として，竹の構造が関係していると考えられる。そのた め, SEM を用いて竹粉末の状態, $\mathrm{Ca}(\mathrm{OH})_{2}$ 担持竹粉末の状態 の観察を行った。SEM 写真を Fig. 5, Fig. 6 に示す。

Fig. 5 に示したように竹は多孔構造であり，広い表面積を 持っている。また，Fig. 5 と Fig. 6 を比較してみると，粉末状 の $\mathrm{Ca}(\mathrm{OH})_{2}$ は竹の表面に広く分布しているのを確認できた。 $\mathrm{Ca}(\mathrm{OH})_{2}$ が竹の表面に分布することで，竹バイオブリケット 燃焼する際，フッ素との接触確率が高く，フッ素との反応率 が高くなり，高い脱フッ素率に繋がったと考えられる。

\section{5 竹バイオブリケットの脱硫について $\left(900{ }^{\circ} \mathrm{C}\right)$}

Fig. 7に蓮塘炭ブリケットと上述二種の竹バイオブリケット の $900{ }^{\circ} \mathrm{C}$ で然焼時における $\mathrm{SO}_{2}$ 放出状態を示す。Fig. 7 に示し たように，三種のブリケットの燃焼過程では，蓮塘炭ブリケッ 卜を燃焼時の $\mathrm{SO}_{2}$ 放出量が最も多かった。これは，上述二種 の竹バイオブリケットを燃焼時，式(3)，式(4)により脱フッ 素反応を起こると共に, 式(5)の脱硫反応も起こる。しかし, 蓮塘炭ブリケット中はCa $(\mathrm{OH})_{2}$ を含まれなかったため, 式 (5) の脱硫反応が起こらなかったと考えられる。
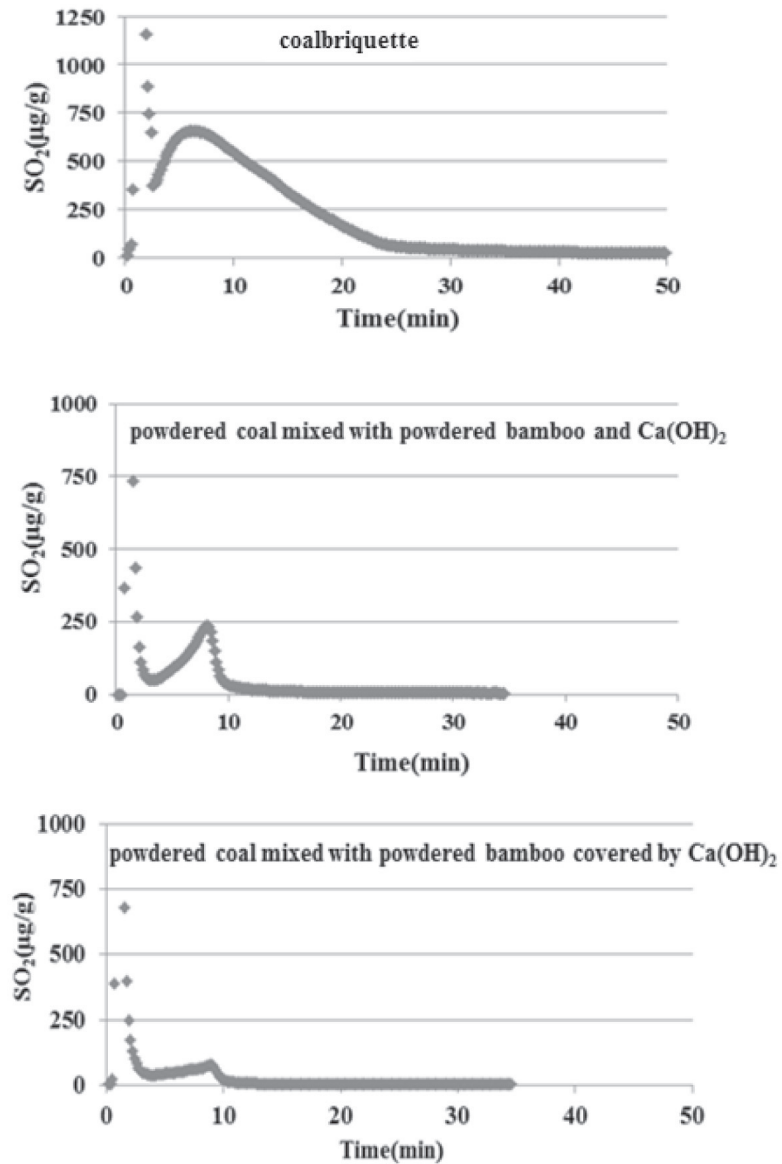

Fig. 7 Comparison of exhausted $\mathrm{SO}_{2}$ between three sorts of biobriquettes $\left(900{ }^{\circ} \mathrm{C}\right)$
$\mathrm{CaO}+\mathrm{SO}_{2}+1 / 2 \mathrm{O}_{2}+2 \mathrm{H}_{2} \mathrm{O}=\mathrm{CaSO}_{4} \cdot 2 \mathrm{H}_{2} \mathrm{O}$

また，Fig.7から，蓮塘炭ブリケットの燃焼時間は竹バイオ ブリケットより長いことが判明した。これは，蓮塘炭ブリケッ トの密度が竹バイオブリケットより高いため, 燃焼する際, 酸 素の蓮塘炭ブリケット内部への拡散速度が遅く，燃焼に時間 がかかったと考えられる ${ }^{21)}$ 。一方，竹バイオブリケット中に はバイオマスが20wt\%を占めるため, 密度は蓮塘炭ブリケッ 卜より低く, 酸素の竹バイオブリケット内部への拡散速度が 速く，燃焼性がよくなったことで燃焼時間が短い。また，こ の実験により, $\mathrm{Ca}(\mathrm{OH})_{2}$ 担持竹バイオブリケットの $\mathrm{SO}_{2}$ 放出 量が $\mathrm{Ca}(\mathrm{OH})_{2}$ を混合した竹バイオブリケットより少ないこと が判明した。その原因として, $\mathrm{Ca}(\mathrm{OH})_{2}$ 担持竹バイオブリケッ 卜の場合は, $\mathrm{Ca}(\mathrm{OH})_{2}$ が竹粉末表面に広く分布することで, $\mathrm{SO}_{2}$ との接触確率が高くなり, 式(5)に示したような脱硫反応 が促し, 脱硫率が高くなったためと考えられる。上述三種ブ リケット燃焼時の $\mathrm{SO}_{2}$ 排出量を用いて, 式 (2)より脱硫率を算 出した結果, $\mathrm{Ca}(\mathrm{OH})_{2}$ 担持竹バイオブリケットの方が $85 \%$ で あり, $\mathrm{Ca}(\mathrm{OH})_{2}$ を混合した竹バイオブリケットの $65 \%$ より高 くなった。

\section{4. 結 論}

本研究は竹をバイオマスとして竹バイオブリケット作製し, 民生用石炭として使用する際の炉内脱フッ素について検討を 行った。その結果，竹にはフッ素が含まれることが判明した。 また, 脱フッ素剤を使用しないと, 竹自身は石炭燃焼時の脱 フッ素剂になれないことがわかった。

$\mathrm{Ca}(\mathrm{OH})_{2}$ を脱フッ素剂，脱硫剤として，モル比 $\mathrm{Ca} /\left(\mathrm{F}_{2}+\mathrm{S}\right)$ $=2$ の割合で $\mathrm{Ca}(\mathrm{OH})_{2}$ を担持した竹粉末で作製した竹バイオ ブリケットと $\mathrm{Ca}(\mathrm{OH})_{2}$ を混合した竹バイオブリケットを作製 し，燃焼を行った。その結果， $\mathrm{Ca}(\mathrm{OH})_{2}$ を担持した竹粉末を用 いたバイオブリケットの方は高い脱フッ素率と脱硫率を得た。 これは竹粉末が多孔質であるため表面積が大きく, Ca $(\mathrm{OH})_{2}$ が 竹表面に広く分布することで，フッ素， $\mathrm{SO}_{2}$ との接触確率が高 くなり, 脱フッ素反応と脱硫反応が進行し, 脱フッ素率と脱 硫率が上昇していたと考えられる。なお，竹バイオブリケッ 卜の燃焼温度が高くなると，脱フッ素率が低くなることが明 らかになった。これは, 燃焼温度が高くなると, 石炭中に含 まれた無機フッ素化合物の熱分解率が高くなることにより フッ素の放出量が多くなり, また, 有機フッ素化合物の燃焼 率が高くなることによりフッ素の放出量が多くなるため，力 ルシウムとフッ素のモル比が低くなることで反応率が低くな り，脱フッ素率が低くなったと考えられる。

本研究は, 竹バイオマスの熱エネルギーの有効利用と石炭 のクリーンなエネルギーとしての燃焼が示された。

\section{文 献：References}

1) BP Statistical Review of World Energy, June 2010

2）国立環境研究所特別研究報告, 石炭燃焼に伴う大気污染に よる健康影響と疾病予防に関する研究，SR-33-2000, 5 (平成 6 -10年) 
3）鄈寶山，地方におけるフッ素中毒と工業フッ素污染の研 究，(北京 中国環境科学出版社), p. 176-185(1992)： Zheng, B.S., Research on Fluoride Poisoning and Industrial Fluorine Pollution, (Chinese Environment Science press), p. $176-185(1992)$

4) Qu, C., KEO DISCUSSION PAPRE, No.G-149, p.5-6 (2001)

5) Environmental Health Criteria 36:Fluorine and Fluorides (World Health Organization Geneva), p. 77 (1984)

6）劉丹，西岡将輝，定方正毅，日工六誌，82(9), 679-685 (2003) : Liu, D., Nishioka, M., Sadakata, M., J.Jpn. Inst. Energy, 82 (9), 679-685(2003)

7) 劉丹, 東京大学博士論文 (2004)

8) Liu, D., Sakai, Y., Yamamoto, M., Satakata, M., Energy\&Fuels, 20, 1406-1410 (2004)

9) Liu, D., Satakata, M., Journal of Ecotecnology Research, 8 (2), 120124(2002)

10）ICUE研究報告，2009-2010年の中国洗炭業界及び発展予測 報告，(2009.3)

11）山田辰雄編，豆炭実験と中国の環境問題，（慶応義塾大学 出版社), p. 18(2001)

12）定方正毅，中国環境問題にとりこみ，(岩波新書)，p. 106$111(2000)$
13）慶応義塾大学産業研究所編，アジアの経済発展と環境保全 第 3 巻，(慶応義塾大学出版社), p. 17-28(2002)

14）国家統計局工業交通統計司編，中国の能源統計年鑑，(中 国統計出版社)，(2007)

15) Li, D., Chen, Z., Hu, P., Chen, L., Ni, W., Development and Characteristics of Cold Biomass Palletizing Technology in China, The Proc. of 2nd World Conference on Pellets, pp. 17 (Jonkoping Sweden,30 May-1 June,2006)

16）竹内善幸, バンブー・フアインケミカルズ(その1), 地球 を笑顔に! (第25回)，p.2(経済産業省，中国経済産業局広 報誌 (2010年))

17) Kim, H., Lu, G., Li, T., Dadakata, M., Energy\&Fuels, 17, 1239$1243(2003)$

18）定方正毅, 大気クリーン化のための化学工学，(培風館), p. 193-194(1999)

19）山田隆信ら, 森林バイオマスとしての人工林残渣执よび竹 の低コスト搬出，H15年度農畜林成果発表会，（2004年 3 月19日, 山口県)

20）秋吉将史，有明高専卒業論文，(2007）

21）劉丹，定方正毅，日エネ誌，83(5)，360-366(2004)：Liu, D., Sadakata, M., J. Jpn. Inst. Energy, 83 (5), 360-366 (2004) 